\title{
Atomic Theories That Preservice Science Teachers Confuse and Underlying Reasons $^{1}$
}

\author{
${ }^{2}$ Volkan Bilir, ${ }^{2}$ Azize Digilli Baran, ${ }^{2}$ Sedat Karaçam \\ ${ }^{2}$ Duzce University
}

\begin{abstract}
Students come across with the notion of atom almost every year during their education life. Higher conceptual understandings of atomic theories among science teachers is of crucial importance in their understanding of physics and chemistry courses. In this sense, the purpose of the present study is to investigate which of the atomic theories science teachers often confuse and to discuss the possible reasons behind the confusion of one theory with the other. This study used the phenomenology method of qualitative research. Participants of the study were comprised of 55 first and second year university students attending the Department of Science Teaching during the 2015-2016 academic year. In order to discover the most confusing atomic theories and the reasons of this confusion, students were asked to write down the atomic theories that they often confuse with one another and the reasons why they do so. Using content analysis, two independent coders analyzed the collected data. The result of the analyses revealed that students mostly got confused between Bohr's Atomic Theory and Modern Atomic Theory. It was also found that the underlying reasons of this confusion were that "In both theory, the protons and neutrons are found together at the center of the atom (the nucleus) surrounded by electrons spinning around it" and "students cannot differentiate between the concepts of layer, orbit and shell", and some recommendations were offered concerning the instruction of these subjects.
\end{abstract}

Keywords: Atom, Atomic theories, Science education

\section{İnönü University}

Journal of the Faculty of Education Vol 19, No 1, 2018

pp. 212-220

DOI: $10.17679 /$ inuefd.331368

\section{Suggested Citation}

Bilir V., Digilli Baran A. \& Karaçam, S. (2018). Atomic theories that preservice science teachers confuse and underlyıig reasons. Inonu University Journal of the Faculty of Education, 19(1), 212-220. DOI: 10.17679/inuefd.331368

\footnotetext{
${ }^{1}$ This study was presented as an oral presentation in the 12th National Science and Mathematics Education Congress
} 


\section{INTRODUCTION}

\section{Evolution of the Concept of the Atom}

The first scientific views on the existence of atom were put forward by the Greek philosophers. Around 440 B.C., Leucippus was first to develop the concept of the atom. Leucippus proposed that all matter was composed of small particles invisible to the naked eye and called them atoms, which means indivisible. His pupil Democritus (470-370 B.C.) shared his own views about the atom, as well. According to Democritus, atoms involve uniform objects and the different positions and arrangement of the atoms explain why each matter around us is different from the other (Bahar, Gündüz, \& Doğan, 2006). Democritus argued that there exist atoms in different shapes and colors; the atoms of oil, for example, are round and smooth or slippery while those of vinegar are sharp-pointed. He expressed that our bodies are composed of coarse atoms and our souls made of fine atoms (Saruhan \& Özdemirci, 2005). Aristotle questioned the idea that atom is indestructible. The atomists theorized that the nature consists of two fundamental principles: atom and void. All matters and elements are different from each other. Properties of matter can be explained through the shapes of the atoms that build the matter. For instance, sweet things are made of smooth atoms, whereas acidic ones have sharp-pointed atoms. The shapes of objects are determined by their atoms. These views of Greek philosophers did not mature enough to be a theory (Kranz, 1994; Marks, 2002). In Figure 1 were summarized the names of the Ancient Greek Philosophers and the dates they presented their views.

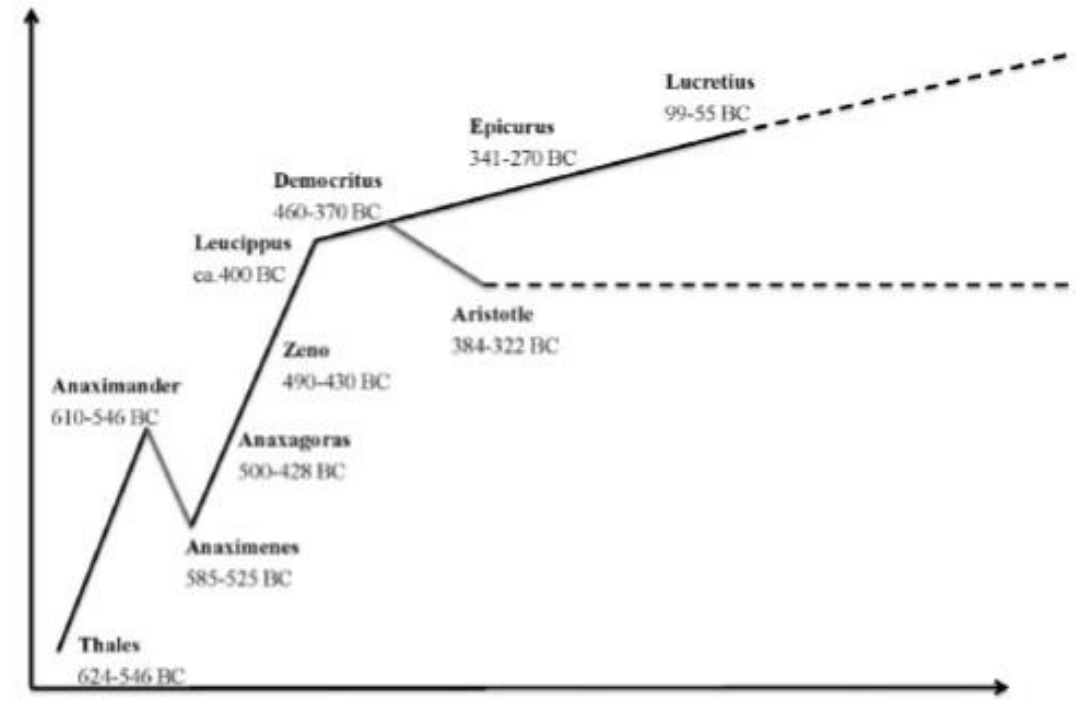

Figure 1. The emergence and development of the notion of atom during ancient period (Unver \& Arabacioglu, 2015)

In 1805, Dalton proposed his theory of atom that explained the mass relationships in chemical reaction. As this theory was considered to be inadequate to explain the new information related to the atom, Thomson, in 1897, came up with the atomic theory called the "plum pudding model", according to which the "atoms are positive spheres with negative charges embedded in them". By 1911, Rutherford thought that Thomson's model might not be correct and therefore performed experiments to test the plum pudding model. The results he obtained seemed to be contradictory to the plum pudding model. Rutherford suggested "the positive charge and mass are concentrated in the centre of the atom which he called the nucleus". In time, some other theories were proposed since this theory failed to give reasons for the motions of the electrons existing in the atoms and it could not explain the spectra of atoms having more than one electron. Taking into consideration some problems of Rutherford's atomic theory, Bohr, in 1913, proposed the atomic theory, what is now called the Bohr's model of the atom, in which he explained the hydrogen atom and behaviours of some single-electron ions. Yet, this theory could not explain the behaviours of multiple electron atoms, either. Today's modern atomic theory has been developed with the contributions of Schrödinger and Heisenberg (Arık \& Polat, 2002). 


\section{The Concept of the Atom in Chemistry Education}

The science of chemistry is a learning area that heightens the level of the perception of invisible and untouchable concepts and makes it possible to understand the information that we directly cannot detect through our sensory organs. The atom and its structure that we cannot see directly and therefore have to visualize was considered to be one of the core subjects within the change process from Democritus to Quantum Theory (Demirci, Yılmaz \& Şahin, 2016). Understanding the relationships of atoms and molecules underlies the chemistry (Whitten, Davis, Peck, \& Stanley, 2009).

Atom has been explained through atomic models since its discovery, and teachers therefore try to explain the structure of atom using these models to help their students understand its structure more easily (Podolefsky \& Finkelstein, 2006; Jong, 2009). Atom is the key concept in science teaching and learning (Erduran, 2014). The view that the matter actually is composed of tiny participles called atom dates back to the 5th century BC. Since then, a large number of atomic theories have been proposed and each atomic theory has revealed and remedied the shortcomings of the previous ones, resulting in the emergence and development of today's modern atomic theory. Modern chemistry has been developed based on the modern atomic theory and therefore understanding the structure of the atom and the interactions of the atoms is crucial in teaching science at schools (Mortimer, 2004). Atom is a concept that is growing in importance along with the development of science and technology which is one of the building blocks of the science. For that reason, day by day it has been growing in importance to organize the teaching of the concept of atom in accordance with the requirements of students (Çökelez \& Yalçın, 2012). The structure of atom can be considered one of the basic subjects in science education. It is hard to comprehend subjects such as structure of the matter, chemical reactions and chemical bonds without knowing the structure of atom (Maloney, 2007).

Basis of the subjects are determined by concepts. A number of concepts need to be taught in order to teach a certain subject. A large body of research therefore have been conducted on concepts in our country as well as in other countries of the world (Kaya, 2010). Numerous studies have been carried out on the notion of atom. Albenese and Vicentini (1997) performed a study with 30 high school students between the ages of 14-16 and investigated students' ideas about the particle model of matter and the way they are explained by the basic concepts of atom and molecule. Their results indicated all students reported that the concepts of atom and molecule are related to the smallest particle of matter. The structure of atom is an important and central concept to which students have many alternatives and thus having difficulty in understanding (Demircioğlu, Altuntaş Aydın, \& Demircioğlu, 2012). Atomic theory is a scientific theory that has massive impacts in physics and biology as well as in chemistry (Ronan, 1983).

Quantum theory especially has made a breakthrough in the development of science and brought about revolutionary changes in the atomic theory. The model still accepted by scientists today - the electron cloud atomic model - is based on the quantum theory. In this model, electrons are depicted as particles moving around the nucleus within a certain orbital. It refers to the density of the electrons around the nucleus. Nevertheless, the discovery of the atom is still in progress. An exact comprehension of the atomic models from the earliest to the most recent one is of great importance in chemistry and for the history of science. Atomic structure is a central concept in chemistry and science and a correct comprehension of it is difficult due to its abstract structure. Many atomic models have been developed by scientists throughout history because of its abstract structure. These models visually facilitates the perception and comprehension of atomic structure. The difficulties that students face and the mistakes they make while dealing with the structure of atom have been discussed in many studies in literature (Gilbert and Watts, 1983; Griffiths and Preston, 1992).

One of the fundamental shortcomings of school chemistry is that the curriculum does not teach students atomic theories using the related models in connection with the related laws and it does not show that they have explanatory and predictive power enabling their understanding of chemistry. Instead, students have to deal with separate parts of knowledge (Erduran, 2014).

Students refer to Rutherford's atomic theory while trying to describe the theory which they call Modern atomic theory. They come to class with pre-knowledge they have in their mind and their ideas hardly change even though these ideas are wrong (Benson et al., 1993; as cited in Oruncak, 2005). It was seen that 
students learnt atomic theories in secondary education and they insisted on Rutherford's atomic theory though there was an increase in their knowledge.

Kılıç (2010) reported that teachers have difficulty with the concepts related to atomic theories in textbooks and found that some teachers have problems making their students comprehend the concepts of physics while some others cannot associate the new concepts with those previously learnt by students.

Students are faced with the notion of atom almost every year during their education life from secondary school to university. Given science, chemistry and physics courses, a proper understanding of the concept of atom is significant for these school subjects. The purpose of the present study is to investigate which of the atomic theories science teachers often confuse and to discuss the underlying reasons of this confusion and offer recommendations on teaching of these subjects.

\section{METHOD}

In order to investigate which of the atomic theories science teachers often confuse and the underlying reasons, the present study used a phenomenological research method - a qualitative data analysis method (Creswell, 2013). Phenomenology was used as a method for the analysis of the research data. In education research, it is a popular methodology that aims to understand the various ways in which different people experience, perceive or understand the same phenomenon (Entvistle 1997; Prosser \& Trigwell 1999; Wihlborg 2004). In this study, which was carried out during the spring term of 2015-2016 academic year, students were asked to write down on a piece of paper the atomic theories that they often confuse with one another and the reasons why they do so. To this end, the data obtained from students were coded by the authors. Categories were made following the revision of codes and a frequency was determined for each category. On the basis of phenomenology, common themes (meanings) were determined according to these frequencies.

\section{Study Sample}

The selection of the sample for this study was based on purposeful sampling. According to Patton (1997), purposeful sampling methods allow in-depth investigation of the given cases. Within the scope of this sampling method, third and fourth year students who had studied the atomic theories in the course "Modern Physics" included in the science teaching program were left out of the study. Study sample therefore was comprised of 58 first and second year students studying at the Department of Science Teaching at Düzce University Faculty of Education in 2015-2016 academic year.

\section{Data Collection Tools and Analysis}

In order to determine which atomic theories students confuse and find out its reasons, students were given a piece of paper to answer the question "Which atomic theories do you often confuse and what are your reasons for confusing them?" They were given 30 minutes to complete this task.

The data obtained from the students was coded by two field experts using content analysis. The process was started over again after each ten students and codes given were revised. In this way, the consistency between assigned codes was ensured. Following the completion of coding, three field experts came together to check the consistency between the codes given for the data segment by two coders. It was found that 8 out of 58 codes assigned by the two coders showed inconsistency. These inconsistent codes were discussed and then revised properly. The approach developed by Miles and Huberman (1994) was used to determine the rate of consistency between the codes given by the two coders and the results showed a consistency of $86.21 \%$ between the codes assigned by the two coders

\section{RESULTS}

In this section, the results of the analyses will be presented in two main parts. In the first part, there are atomic theories that preservice teachers often confuse and the second part presents the reasons why they confuse them. 
The frequency and the percentage distributions of the atomic theories that participating preservice teachers confused were presented in Table 1 .

Table 1. Results regarding which atomic theories students confuse

\begin{tabular}{lcc}
\hline Atomic Theories Confused & Number of Students & $\%$ \\
\hline Bohr's Atomic Theory-Modern Atomic Theory & 28 & 48.277 \\
\hline $\begin{array}{l}\text { Rutherford's Atomic Theory- Bohr's Atomic } \\
\text { Theory }\end{array}$ & 16 & 27.586 \\
\hline $\begin{array}{l}\text { Rutherford's Atomic Theory- - Modern Atomic } \\
\text { Theory }\end{array}$ & 7 & 12.069 \\
\hline $\begin{array}{l}\text { Thomson's Atomic Theory-Dalton's Atomic } \\
\text { Theory }\end{array}$ & 3 & 5.172 \\
\hline $\begin{array}{l}\text { Bohr's Atomic Theory -Thomson' Atomic } \\
\text { Theory }\end{array}$ & 2 & 3.448 \\
\hline $\begin{array}{l}\text { Thomson Atomic Theory- Rutherford's Atomic } \\
\text { Theory }\end{array}$ & 2 & 3.448 \\
\hline Total & 58 & 100 \\
\hline
\end{tabular}

As seen in Table 1, preservice science teachers were mostly confused between Bohr's and Modern Atomic Theories and between Rutherford's and Bohr's Atomic Theories. Although preservice teachers reported that they were also confused between other atomic theories, we mainly focused on the reasons why preservice teachers confused Bohr's and Modern Atomic Theories and Rutherford's and Bohr's Atomic Theories as they caused the greatest confusion among the preservice teachers. The relevant results were given in part two.

\section{What are the reasons that preservice teachers confuse atomic models?}

Frequency and percentage distributions of the data regarding the reasons that students mostly confused Bohr's and Modern Atomic Theories are presented in Table 2.

Table 2. The reasons why students confuse between Bohr's and Modern atomic theories

\begin{tabular}{lcc}
\hline Reasons for confusion & Number of Students & $\%$ \\
\hline $\begin{array}{l}\text { Being unable to distinguish between the concepts } \\
\text { of orbit and layer }\end{array}$ & 12 & 42.857 \\
\hline Similarity of modelling shapes & 7 & 25.00 \\
\hline $\begin{array}{l}\text { In both atomic theories, protons and neutrons are } \\
\text { placed in the nucleus surrounded by electrons }\end{array}$ & 5 & 17.857 \\
\hline Sequence of electrons & 2 & 7.143 \\
\hline I do not know the reason & 2 & 7.143 \\
\hline Total & 28 & 100 \\
\hline
\end{tabular}

The followings are some of the reasons shared by students who reported that they mostly confused Bohr's and Modern Atomic Theories.

S-1: Modern Atomic Theory and Bohr's Atomic Theory because both have electrons orbiting around the nucleus.

S-2: Modern Atomic Theory and Bohr's Atomic Theory because both have electrons and protons. Though it is commonly said that modern atom model is formed out of a cloud of dust, it is difficult to distinguish in practical terms. Actually, Bohr's and Rutherford's models are very much alike, yet the presence of neutrons in Bohr's model but not in Rutherford's model helps us distinguish between them. On the other hand, I find it difficult to distinguish between Modern and Bohr's Models unless the cloud of dust is not put into consideration. 
S-3: I confuse Bohr's and Modern Atomic theories. Because of its structure of nucleus, Bohr's theory predicts definite orbit for revolving electron whereas modern atomic theory suggests that electrons only do not have a definite orbit. I think I confuse them with each other as I have difficulty in understanding the reason behind this.

Based on the ideas shared by S-1, S-2 and S-3, we see that students cannot distinguish between the concept of orbit in Bohr's atomic theory and the concept of layer in Modern atomic theory and they therefore confuse these two atomic theories with each other.

S-4: I confuse Bohr's and Modern atomic theories with each other. Similarities of these theories are easy to notice at first glance. Their orbits, the electrons moving randomly in definite orbits and the presence of protons and neutrons in the nucleus... Similar shapes of these two models of atom is the main factor why I mix them up.

S-5: I mostly confuse Bohr's atomic theory and Modern Atomic theory because they are very similar in their orbits, sequence of electrons or nucleus. Both have electrons traveling in orbits. Their models are the same. There are protons and neutrons in their nucleus.

The ideas shared by S-4 and S-5 indicate that the rationale behind why students confuse Bohr's and Modern atomic theories is the similarity of modelling shapes of these theories.

S-6: The two theories I confuse are Bohr's and Modern atomic theories. In both theory, the protons and neutrons are found together in the nucleus surrounded by electrons moving around it.

S-7: Most of the time, I confuse Bohr's and Modern atomic theories. I do because protons, electrons and neutrons are all located in the same area.

Based on the views of S- 6 and S-7, we see that these students confuse these two atomic theories because protons and neutrons are located in the nucleus and the electrons are around the nucleus in these two atomic theories.

The analysis of the responses from preservice teachers indicate that the reasons why they confuse Bohr's and Modern atomic theories can be summarized as follows; "there are protons and neutrons in the nucleus surrounded by electrons in Modern and Bohr's atomic theories", "I cannot distinguish between the concepts of orbit and layer" and "Bohr's and Modern atomic theories are very much alike in terms of their shapes of atomic models".

Other two theories that preservice teachers often confuse with each other are Bohr's and Rutherford's atomic theories. The frequency and percentage distributions of the data obtained for the reasons that teacher candidates confused these two atomic theories are presented in Table 3.

Tablo 3. Results of the reasons that students confuse Bohr's and Rutherford's atomic theories

\begin{tabular}{lcc}
\hline Reasons for Confusion & Number of Students & $\%$ \\
\hline Similarity of modelling shapes & 9 & 56.25 \\
\hline The Concept of Orbit in Both Theories & 5 & 31,25 \\
\hline I do not know the reason & 2 & 12,50 \\
\hline Total & 16 & 100 \\
\hline
\end{tabular}

Other theories that preservice teachers often confuse with each other are Bohr's and Rutherford's atomic theories. Preservice teachers explain why they confuse these theories as follows:

S-8: I confuse Bohr's and Rutherford's atomic theories because they are alike in appearance and it is hard to decide which model belongs to which theory.

S-9: I am a bit confused about the difference between Rutherford's and Bohr's atomic theories as there are protons and neutrons in the center of orbits in both theories. 
Based on the responses received from S-8 and S-9, we can conclude that the main reason why these two atomic theories are confused with each other is that the models developed out of these two theories are very similar in appearance.

S-10: I mostly confuse Rutherford's and Bohr's atomic theories. Both have orbits. They are very much alike in their properties. That is why they are confused with each other.

S-11: The atomic theories I confuse a lot are the ones developed by Bohr and Rutherford. Both have the concept of orbit.

The existence of orbits in both theories was found to be the main reason that S-10 and S-11 had confusion about these two theories.

Based on the responses from preservice teachers, two points stand out as the reasons why Bohr's and Rutherford's atomic theories are confused with each other; "Both models are similar in terms of their shapes" and "Both theory postulate that atom is made up of orbits"

\section{CONCLUSION, DISCUSSION AND RECOMMENDATIONS}

The present study conducted on atomic theories found that preservice science teachers confuse many atomic theories and the greatest confusion arises between Modern and Bohr's atomic theories. Harrison and Treagust (1996) reported Modern atomic theory was the least preferred one though it was taught to students in class. It was stated that students could not properly understand this theory. Similarly, Podolefsky and Finkelstein (2006) noted that the existence of more than one theory (Thomson, Rutherford, Bohr) about the structure of atom and the use of models in relation to these theories lead to confusion among students.

Kahraman (2010) found that majority of students confuse Bohr's model with Thomson's model and Modern atomic model with Bohr's atomic model. The finding that students confuse Modern atomic model and Bohr's model seems to be consistent with the result of our study. In addition, it was revealed that students have various misconceptions about the electron structure of hydrogen atom. As in the question above, this question also indicated that students, prior to the implementation, regarded orbital as an orbit, visualized electrons as particles moving in these orbits and described it as Modern atomic theory.

In another study, the reasons why students confuse atomic models were summarized as follows; "Models are very similar to each other in their shapes", "The arrangement of electrons and nucleus are very much alike" and "The concepts of orbit and layer cannot be distinguished easily". In this respect, it can be suggested that students have difficulty understanding the point that electrons in the modern atomic model have no exact position and therefore need to be defined as electron cloud, based on Heisenberg's Uncertainty Principle. Harrison and Treagust (1996) also reported that students could not distinguish between Bohr's and Modern atomic models, as they do not clearly perceive the concepts of orbit and electron cloud. Another study with preservice science teachers found that student's images related to the images of atomic models showed they had inaccurate images of Thomson's, Rutherford's and Modern atomic models (Bilir, Digilli Baran \& Karacam, 2016).

The analysis of the data obtained in this study showed that preservice science teachers often confuse Bohr's and Modern atomic theories and Rutherford's and Bohr's atomic theories. It was found that preservice science teachers confuse these theories because "there are protons and neutrons in the nucleus surrounded by electrons" and "the concepts of layer and orbit are confused with each other". The results obtained in this study were found to be consistent with those of other studies (Cokelez \& Dumon, 2005 Kaya, 2010; Küçükönder, Söğüt \& Büyükkasap, 2005).

It might be thought that though historical models of atom and Modern atomic theories are taught, most of the recent knowledge cannot be expanded unless it is replaced by the old one and there is therefore a necessity to mention in details De Broglie's approach to the participle, Balmer's studies and the effect of Quantum theory during the transition from Rutherford's atomic theory to Bohr's atomic theory and 
Heisenberg's uncertainty principle during the transition from Bohr's atomic theory to Modern atomic theory. At this point, enriching the learning with different methods and techniques can make the achievements of the students more permanent.

While teaching atomic theories in chemistry classes, it should be noted that some theories are outdated nowadays and it needs to be ensured that the subject is fully comprehended by students by explaining the reasons why one theory was replaced with the other and by emphasizing that every new theory has remedied the shortcomings of the previous one. It is recommended that these theories be taught as a whole in the same classroom to avoid disconnections between the subjects.

Providing consistent information, the historical development of atomic theories need to be included in the textbooks and the limitations and shortcomings of these theories should also be mentioned.

Using too much scientific terminology could be a reason students tend to choose simpler models. In this respect, it will probably help if a more proper curriculum and teaching process consistent with their cognitive level and constructed knowledge is followed.

\section{REFERENCES}

Arık, A. \& Polat, R. (2002). Lise kimya 1 ders kitabı. İstanbul: Oran Yayıncılık.

Albenese, A. \& Vicentini, M. (1997). Why do we belive that an atom is colourless? reflections about the teaching of the particle model, Science \& Education, 6, 251-261.

Bahar, M., Gündüz, S. \& Doğan, S. (2006). Bilim Tarihine Kısa Bir Bakış (Editör: Mehmet Bahar) Fen ve Teknoloji Öğretimi içinde 1-32, Ankara: PEGEMA Yayıncılık.

Bilir, V., Digilli Baran, A., \&. Karaçam, S. (2016). "The science teacher candidates' images related to atom models", International Congresses on Education. Sarajevo/Bosnia and Herzegovina (2-4 June).

Creswell, J.W. (2013). Nitel araştırma yöntemleri (Çev.ed. Bütün, M. ve Demir, S.B.). Ankara:Siyasal Yayıncılık.

Cokelez, A. \& Dumon, A. (2005). Atom and molecule: upper secondary school french students' representations in long-term memor, Chemistry Education Research and Practice, 6 (3), 119-135, 2005.

Çökelez, A. \& Yalçın, S. (2012). İlköğretim 7. sınıf öğrencilerinin atom kavramı ile ilgili zihinsel modellerinin incelenmesi, ilköğretim Online, 11(2), 452-471, 2012.

Demirci, S. \& Yılmaz, A \& Şahin E. (2016). Lise ve üniversite öğrencilerinin atomun yapısı ile ilgili zihinsel modellerine genel bir bakış. Journal of the Turkish Chemical Society Chemical Education, Cilt 1, Sayı 1,2016

Demircioğlu, G. Altuntaş Aydın, M., \& Demircioğlu, H. (2012). Kavramsal değişim metninin ve üç boyutlu modelin 7. sınıf öğrencilerinin atomun yapısını anlamalarına etkisi, Bayburt Eğitim Fakültesi Dergisi, Cilt 7, Sayı 2, 2012.

Entwistle, N. (1997). Introduction: Phenomenography in higher education. Higher Educ. Res. Dev. 16, 127.

Erduran, S. (2014). A holistic approach to the atom in school chemistry. Educació Química EduQ número 19, p. $39-42$

Gilbert, J.K. \& Watts, D.M. (1983). Concepts, misconceptions and alternative conceptions: changing perspectives in science education, Studies in Science Education, 10, 61-98.

Griffiths, A.K. \& Preston, K.R. (1992). Grade-12 students' misconceptions relating to fundamentel charecteristics of atoms and molecules, Journal of Research in Science Teaching, 29, 6, 611-628.

Harrison, A.G. \& Treagust, D. F. (1996). Secondary students' mental models of atoms and molecules: Implications for teaching chemistry, Science Education, 80, 5, 509-534. 
Jong, O.D. (2009). How to teach scientific models and modelling: A study of prospective chemistry teachers' knowledge base, International Journal of Science Education, 31(6), 829-850.

Kahraman, S. (2010). Atomun yapısı ve orbitaller konusunda geliştirilen üç boyutlu bilgisayar destekli öğretim materyallerinin öğretmen adaylarının başarısı ve tutumlarına etkisi, Atatürk Üniversitesi Fen Bilimleri Enstitüsü Ortaöğretim Fen ve Matematik Öğretmenliği Anabilim Dalı Doktora tezi

Kaya, A. (2010). Fen bilgisi öğretmen adaylarının ışık ve atom kavramlarını anlama seviyelerinin tespiti. Erzincan Eğitim Fakültesi Dergisi, 12 (1), 15-37, 2010

Kılıç, F. (2010). Ortaöğretim kimya ders kitaplarında atom teorilerinin sunumunun bilim tarihi ve felsefesi açısından incelenmesi ve öğretmen görüşleri, Gazi Üniversitesi Eğitim Bilimleri Enstitüsü Ortaöğretim Fen ve Matematik Öğretmenliği Anabilim Dalı Yüksek Lisans Tezi.

Küçükönder, A., Söğüt, Ö. \& Büyükkasap, E. (2005). Education faculty students' ideas about fundamental characteristic of atoms and models. Gazi Eğitim Fakülktesi Dergisi, Sayı 3, 339-347.

Kranz, W. (1994). Antik Felsefe, (cev) Suad Y. Baydur, İstanbul: Sosyal Yayınlar.

Maloney, J. (2007). Children's roles and use of evidence in science: an analysis of decision-making in small groups. British Educational Research Journal, 33(3), 371-401.

Marks, K. H. (2002). Demokritos ile epikuros'un doğa felsefelerindeki ayırım. (cev) Saffet Babur, Ankara: Ayrac Yayınları,

Miles, M. B., \& Huberman, M. A. (1994). An expanded source book qualitative data analysis. London: Sage.

Mortimer, C.E. (2004). Modern üniversite kimyası, cilt 1, çev. altınata, t., Beşinci Baskı, Çağlayan Kitabevi, 2004, İstanbul.

Oruncak, B. (2005). Ortaöğretim ve yüksek öğretimde öğrencilerin atom kavramı ile ilgili algıları ve bunun eğitim kesiti içerisindeki değişimi, S.D.Ü. Fen Bilimleri Enstitüsü (Fizik Eğitimi) Doktora Tezi, Isparta.

Unver Oguz, A. \& Arabacioglu, S. (2015). Helping pre-service science teachers to understand atomism through observations and experiments, Journal of Baltic Science Education, Vol. 14, No. 1, 2015

Prosser, M. \& Trigwell, K. (1999). Understanding Learning and Teaching. The Experience in Higher Education, Buckingham, U.K.

Patton, J. E. (1997). A life skills approach to mathematics instruction: Preparing students with learning disabilities. Journal of Learning Disabilities, 30(2), 178.

Podolefsky, N.S. \& Finkelstein, N.D. (2006). The use of analogy in learning physics: the role of representations.Phys. Rev., ST - Phys. Educ. Res. 2, 020101.

Ronan, C. A. (1983). Bilim tarihi- dünya kültürlerinde bilimin tarihi ve gelişmesi.( çev: e. ihsanoğlu, $f$. Günergun,) Tübitak yayınları/ Akademik Dizi I.

Saruhan, Ş. C. \& Özdemirci, A. (2005). Bilim, Felsefe ve Metodoloji. İstanbul: Alkım Yayınevi

Wihlborg, M. (2004). Student nurses' conceptions of internationalism in general and as an essential part of Swedish nurses'education. Higher Educ. Res. Dev. 23, 433.

Whitten K. W., Davis R.E., Peck L. \& Stanley C. G. (2009). Chemistry, 9th edition, Brooks Cole, ISBN 978-0-49539163-0

İletișim/Correspondence

Dr. Öğr. Ü. Volkan BíLiR

volkanbilir@duzce.edu.tr

Arş. Gör Azize DigilLi BARAN

azizedigilli@duzce.edu.tr

Doç. Dr. Sedat KARAÇAM

sedatkaracam@duzce.edu.tr 